\title{
CERITA ASING YANG DIGEMARI ANAK SD: SEBUAH KAJIAN UNSUR INTRINSIK
}

\author{
Ida Bagus Sutresna ${ }^{1}$, I Wayan Rasna ${ }^{2}$, Ni Wayan S. Binawati ${ }^{3}$ \\ 1, 2 Jurusan Pendidikan Bahasa dan Sastra, Fakultas IImu Sosial, \\ Universitas Pendidikan Ganesha, Singaraja, Indonesia \\ ${ }^{3}$ Unit MPK, Universitas Pendidikan Ganesha, Singaraja, Indonesia
}

\begin{abstract}
Abstrak
Penelitian ini bertujuan mengkaji cerita asing yang digemari anak SD dari sudut unsur intrinsik. Lokasi penelitian ini ialah SD 1 dan 3 Banjar Jawa sebagai SD kota; SD 1 Sangsit dan SD 1 Temukus sebagai SD pinggiran; dan SD 2 Jinengdalem dan SD 2 Banjar sebagai SD desa. Subjek diambil dengan teknik stratified random sampling dengan jumlah sampel 180 orang (30 orang tiap SD). Data dikumpulkan dengan kuesioner untuk data kegemaran dan tes untuk data pemahaman unsur intriksik. Data dianalisis secara kualitatif. Hasil penelitian menunjukkan bahwa unsur intrinsik cerita merupakan unsur penting yang mempengaruhi kegemaran anak terhadap cerita. Sebab itu, pengarang cerita anak, perlu mengemas cerita anak dengan bangunan struktur intrinsik yang kokoh dan apik.
\end{abstract}

Kata kunci: Anak, Cerita, Digemari, Intrinsik.

\begin{abstract}
This study aims at investigating the intrinsic elements of foreign stories which primary school kids are interested in. The locations of this study were primary schools 1 and 3 Banjar Jawa as city primary schools, primary schools 1 Sangsit and primary school 1 Temukus as outskirt primary schools, primary school 2 Jineng Dalem and primary school Banjar as country primary schools. The subjects of the study were determined by using Stratified Random Sampling Technique with the number of samples 180 kids (30 kids in each primary school). The data related to interest or preference, were collected through questionnaire, while the data concerning the understanding of intrinsic elements were collected through test. The obtained data were then analyzed qualitatively. The result of the study shows that the intrinsic elements of the stories are the elements influencing the interests of the primary school kids in stories. The story writers for young kids, therefore, are required to design stories for kids with strong, well organized intrinsic generic structure.
\end{abstract}

Keywords: Kids, Stories, to be interested in, intrinsic elements 


\section{PENDAHULUAN}

\subsection{Latar Belakang}

Sikap altruistik, rela berkorban, tidak mementingkan diri sendiri atau kelompok, solidaritas, melepaskan ego pribadi adalah sebuah sikap hudup yang dalam kehidupan nyata sangat didambakan, dipuja-puja, tetapi saat ini terasa sangat mahal. Keiklasan dan keindahan itu sering hanya dalam tataran ucapan, tetapi kosong dalam kenyataan (Nurono, 2011: 1). Begitulah kenyataan. Sungguh jauh dari materi yang diucapkan. Apabila kita menganggap ucapan itu sebagai sebuah janji yang mungkin kita impikan, mungkin pula kita hanya berhadapan dengan sebuah kepedulian. Seiring dengan hal ini, perilaku, serta budi pekerti pelajar atau remaja sangatlah memprihatinkan (Lisnawati, 2010:1). Lihat saja, betapa orang mudah memiliki senjata api. Untuk apa ? untuk membela diri atau membunuh ? (Nazar, 1995: 18). Keluhan serupa juga muncul bahwa: berbeda dengan pelajar tempo dulu, kini pelajar mulai cenderung bandel (Bali Post, 5 Mei 2006: 1) Selain itu, tindakan kekerasan yang terjadi di kalangan pelajar kian meningkat. Tawuran makin merebak. Hanya dalam waktu tiga minggu di tahun 1996, tiga nyawa melayang.

Data Polda Metro Jaya mengatakan bahwa tahun 1994 tercatat 10 pelajar tewas. Tahun 1995 jumlah pelajar tewas menjadi 13 orang, 19 orang luka berat, 1.245 pelajar ditangkap dan 95 diajukan ke meja hijau (Bali Post, 5 Mei 1996: 15). Kondisi ini menjadi gambaran bahwa telah terjadi pergeseran ukuran normatif di kalangan generasi muda kita, dibandingkan dengan ukuran yang berlaku sebelumnya (Said, 1980: 14). Bunanta mengungkapkan bahwa buku anak-anak yang kita miliki belum memadai kualitasnya, terutama dalam cara pemaparan cerita, menyedihkankah nasib bacaan cerita anak Indonesia ? sementara pendongeng buku "The Little Mermaid" didengarkan dengan penuh antusias oleh anak-anak dengan sorot mata tertuju ke pendongeng, dengan sekali mereka tertawa berbahak-bahak (Kompas, 16 November, 1993: 10). Mungkin keadaan ini menyebabkan masuknya bacaan asing ke Indonesia.

\subsection{Landasan Teori}

Bahasan Kompas 16 November 1993 menyebutkan bahwa buku bacaan anak-anak mengalami kebangkitan. Kebangkitan itu tidak hanya menyangkut tema yang dikemukakan, tetapi juga meliputi ilustrasi, dan dengan demikian akan mengantar mereka mencintai buku, khususnya cerita warisan budaya bangsa yang mempunyai nilai-nilai mendidik. Akan tetapi, kebangkitan buku anak-anak di luar negeri itu agaknya tidak bergaung sampai ke Indonesia. Bahkan dalam delapan tahun terakhir ini, Indonesia mengalami kemunduran dalam penerbitan buku anakanak, baik dari segi judul maupun kualitasnya, Lalu bacaan macam apakah yang diberikan kepada anak-anak ? (Kompas, 16 November, 1996: 1).

Pertanyaan semacam ini tentu bukan pentanyaan sembarang pertanyaan, bukan pertanyaan yang hanya dijawab dalam untaian kata-kata betapa pun manis dan logisnya jawaban itu, melainkan ia memerlukan langkah konkrit berupa perilaku nyata. Memang semua ini memerlukan pengorbanan. Dan pengorbanan itupun bukan hanya pikiran, waktu, tetapi juga biaya.

Pengorbanan pikiran, waktu dan biaya ini tentu bukan hanya dari pemerintah, penerbit. pengarang/pencerita, atau dan

Jurnal IImu Sosial dan Humaniora | 93 
masyarakat, tetapi semuanya. Sebab masalah ini tanggung jawab kita. Sebab melalui cerita, baik yang disampaikan melalui buku maupun tayangan sejumlah nilai kehidupan mulai ditanamkan. (Kompas, 16 November, 1993: 10).

Penanaman kehidupan yang sesuai akar budaya bangsa perlu dilakukan melalui cerita kepada anak-anak.Ini dilakukan karena jiwa manusia tidak boleh kosong dan kering.Jiwa

harus diisi(Nadeak.1987:5).Pengisian ini dilakukan dengan kisah yang bersifat tuturan menarik hati orang karena ia bersifat mengajarkan kebenaran(Kompas 16 November 1993:10 dan Nadeak, 1987:5-6).Oleh karena yang menjadi sasarannya adalah anak-anak, maka penulis cerita anak-anak harus benarbenar mendalami dan memahami dunia anak-anak(Dagmar, 1993:10).)Oleh karena itu, kita perlu memberikan edukasi, menghormati anak-anak, . menghormati agama dan, memiliki kualitas sastra (Despinette, 1993:10).

Berpegang pada konsep Dagmar dan Despinette di atas maka jelaslah, bahwa menulis cerita anak-anak itu tidak mudah(Marcus, 1984:9).Sebab, umumnya anak-anak kecil sulit mengikuti cerita yang mempunyai plot yang berliku-liku, jalan cerita yang rumit dengan bahasa yang abstrak. Itulah sebabnya, cerita semacam itu harus diadaptasi, disesuaikan dengan jalan pikiran dan tingkat pemahaman anakanak.(Nadeak, 1987:6).Artinya pengarang cerita anak-anak hendaknya tekun mempelajari lingkungan hidup anak-anak, ilmu jiwa tentang mereka(Marcus, 1984:11).

Senada dengan pendapat di atas Muhammad Nun menulis "pengarang harus mengetahui cara anak-anak bergaul dengan sesamanya, cara bermain-main dan bercakap-cakap.Pendeknya, pengarang harus menyelami jiwa anak-anak yang sangat diperlukan dalam tulisan yang ditulisnya.(Nun dalam Marcus, 1984:17).Bahkan Sukamto, SA mengatakan pengarang cerita anak perlu mengalami sendiri aneka hidup dan punya konsep yang baik dan jelas, bagaimana manusia Indonesia kelak (Sukamto, 1990:12).Konsep-konsep yang dikemukakan di atas jelas bermaksud agar anak-anak kita dapat mengkomsumsi bacaan cerita yang baik. Bacaan yang baik bagi anak-anak ialah bacaan yang dapat memperkaya fantasi

anak, dan ini akan memperkuat karakter mereka (Umar Kayam dalam Marcus, 1984:17).

Pengalaman sastra itu selalu berdimensi ganda karena melibatkan buku dan pembaca (dalam sastra tulis) atau pencerita dan penyimak (dalam sastra lisan) (Tarigan, 1995 3). Hal ini terjadi karena komunikasi yang sesungguhnya dan lengkap terjadi jika pengirim dan penerima bertukar peran. Artinya penulis sekali-sekali menjadi pendengar atas kesan yang disampaikan anak setelah membaca cerita. Sebaliknya anak menjadi pembicara saat menyampaikan kesannya (Zoest, 1990: 53). Apabila anak mempunyai latar belakang fantasi yang baik maka dia dapat memahami kerumitan plot atau alur, juga dapat mentoleransi logika ketidaklogisan cerita yang dibacanya (Tarigan, 1995: 3). Burka (1990:185) dalam Bunanta (1988: 26) menyebutkan bahwa meskipun fantasi diperlukan sepanjang tingkatan umur, namun puncak kebutuhan fantasi antara umur enam tahun sampai delapan tahun.

Kata-kata dan gambar-gambar mempunyai fungsi yang sangat penting dalam sastra anak-anak. Simbol -simbol atau lambang-lambang tersebut Jurnal IImu Sosial dan Humaniora | 94 
menghasilkan atau rnembuahkan pengalaman estetik bagi anak-anak (Tarigan, 1995:3). Lambang ini menolong pembaca atau penikmatnya untuk merasakan pola-pola, perasaan-perasaan yang membuahkan pengalaman seni yang mendalam. Setelah selesai membaca atau menikmatinya, seperti menonton film cerita anak-anak biasanya penikmat memberikan tanggapan terhadapnya.

Persoalannya adalah, sering tanggapan atau responsi ini terasa ada, terkatakan tiada (Ada terasa, tetapi tiada terkatakan).

Penggunaan bahasa yang imajinatif dapat menghasilkan responsi intelektual dan emosional. Hal ini menyebabkan pembacanya merasakan, menghayati para tokoh, aneka konflik, latar, masalah manusia seperti kesenangan, kemudahan, keajaiban, kelucuan, kesedihan, ketidakadilan dan kekurangajaran. Dari sini anak dapat mengenal orang dan dirinya sendiri (Huck, Hepler \& Hickman, 1987: 4).

Bagaimanapun juga, kita tidak bisa hanya menyoroti anak, orang tua, guru saja, tanpa menyoroti struktur internal (intrinsik) cerita itu. Sebab, anak posisinya sebagai penikmat. Anak sebagai penikmat, justru akan merasa senang dan terpengaruhi budi baiknya, kalau cerita yang disuguhkan kepadanya baik melalui layar televisi maupun media cetak itu memang memiliki kualitas struktur intrinsik yang baik. Sebab itu, unsur instrinsik perlu mendapat kajian secara sistematis seperti berikut ini.

1) Alur

Alur adalah konstruksi cerita yang berupa peristiwa-peristiwa yang secara logis mempunyai kaitan (Luxemburg, 1984 1949). Di sisi lain, Rusyana (1979:110) menyebutkan bahwa alur adalah kisah peristiwa-peristiwa., tetapi peristiwa- peristiwa itu telah disusun dalam struktur sebab-akibat. Dengan demikian sebuah cerita itu pada hakikatnya adalah urutan peristiwa yang mendukungnya. Masih kaitannya dengan alur ini, Wellek dan Austin Warren (1990: 284) mengemukakan bahwa struktur naratif sebuah dongeng, drama, atau novel -secara tradisional disebut alur. Dapat kita ketahui bahwa alur tersebut pada hakikatnya merupakan struktur novel atau cerita itu sendiri. (Huck, 1976: 6 dan Norton, 1983: 202).

\section{2) Penokohan}

Saleh Saad mengatakan bahwa tokoh erat sekali hubungannya dengan alur. Pemyataan ini menunjukkan bahwa peristiwa pada hakikatnya adalah wadah bagi bergeraknya tokoh-tokoh dalam cerita. Wellek dan Warren (1990: 228) menyatakan bahwa ada banyak ragam penokohan. Novelis-novelis lama seperti Scott memperkenalkan setiap tokoh utamanya dalam satu alinea yang menguraikan secara rinci penampilan fisik mereka, dan satu alinea lagi menganalisis sifat moral dan psikologis. Vladimir Proop dalam menelaah dongeng Rusia mengatakan ada 7 tokoh dalam dongeng (Tasai dkk, 1991: 6) (Luthi, 1976: 126 dan Norton 1983: 202).

3) Lalar

Hough (1996) dalam Yus Rusyana (1979: 144) mengemukakan bahwa novel bukan saja terkait hukum kemungkinan keseharian, melainkan juga secara khas terus meningkatkan diri lebih lanjut kepada waktu dan tempat tertentu. Latar ini tidak sekedar insidental, tetapi merupakan bagian yang vital dalam substansinya itu. Hal ini berarti bahwa latar itu mengesankan ruang dan waktu.

Jurnal IImu Sosial dan Humaniora | 95 
Latar adalah lingkungan, dan lingkungan terutama interior rumáh dapat dianggap berfungsi sebagai rnetonimia atau metafora ekspresi dari tokoh (Wellek dan Warren, 1990 290-291). Di sisi lain, Abram dalam Band dkk (1985 78-79) mengemukakan bahwa latar itu di samping tempat terjadinya peristiwa, juga bertalian dengan periode. Ini artinya, latar itu berhubungan dengan tempat dan waktu (Norton, 1983: 86 dan Burke, 1990: 184).

\section{4) Tema}

Menurut Stanton (1965 4) tema adalah sebuah arti pusat yang terdapat dalam cerita yang juga disebut ide pusat. Seperti halnya dengan arti pusat pengalaman-pengalarnan tema cerita mernpunyai nilai khusus atau nilai universal, yaitu memberikan kekuatan dan kesatuan kepada peristiwa yang digambarkan menceriterakan sesuatu kepada seseorang tentang kehidupan pada umumnya. Saad (1996:119) mengatakan bahwa tema ialah sesuatu yang menjadi pikiran, sesuatu yang menjadi persoalan bagi pengarang. $\mathrm{Di}$ dalamnya terbayang pandangan hidup atau cita-cita pengarang, bagaimana ia melihat persoalan itu (Tjitrosubono, . 1985: 26).

\section{5) Gaya Penceritaan}

Penulis yang satu menyatakan pikiran dan idenya berbeda dengan penulis yang lain Oleh karena itu, seorang penulis biasanya dapat dikenal dari cara dan gayanya bercerita, atau dengan kata lain, antara penulis dan gaya penceritaan yang dimilikinya tidak mungkin dipisahkan. Gaya menurut Murry (Lodge, 1969: 49) merupakan idiosyncracy, yaitu keistimewaan dan kekhususan yang dimiliki seorang pengarang, sebagaimana dikatakan Hudson (1963: 27) dalam Tjitrosubono (1985 93) yang menyebutkan bahwa gaya itu adalah orangnya sendiri. Sebab itu, tidaklah mengherankan bila gaya bercerita seorang penulis senantiasa pula memberikan corak serta ciri tersendiri yang khas tulisantulisannya. Meskipun demikian, ada beberapa ha! yang biasanya mempengaruhi pengarang dan gayanya. Di antara faktor yang terpenting ialah lingkungan bidup dan sosial budaya penulis (Hamzah, 1964: 52 (huck, 1976: 11, Smith 1976: 37 dan Norton, 1983: 203)

Sejalan dengan hal ini, hasil survey Research Indonesia mengenai rating (tingkat kepemirsaan) ternyata acara TV untuk untuk anak (susia 5-14) tahun hanya $14 \%$ yang kena sasaran. Artinya hanya 14\% yang acara anak-anak. Sisanya $86 \%$ bukan untuk anak (Kompas, 4 April 1995: 17).

\subsection{Rumusan Masalah}

Sejalan dengan uraian latar belakang seperti diuraikan pada bagian 1.1 di depan, maka rumusan masalah penelitian ini ialah bagaimanakah struktur instrinsik cerita asing yang digemari anak Sekolah Dasar?

\subsection{Tujuan Penelitian}

Penelitian ini mempunyai 2 tujuan yaitu, tujuan umum dan tujuan khusus. Tujuan tersebut dapat dirinci menjadi sebagai berikut.

\subsubsection{Tujuan Umum \\ Tujuan umum penelitian ini ialah} untuk mengetahui struktur intrinsik cerita asing yang digemari anak sekolah dasar.

\subsubsection{Tujuan Khusus}

Tujuan khusus penelitian ini ialah untuk mengetahui:

Jurnal IImu Sosial dan Humaniora | 96 
1) Tema cerita yang digemari anak sekolah dasar

2) Alur cerita yang digemari anak sekolah dasar

3) Perwatakan cerita yang digemari anak sekolah dasar

4) Latar cerita yang digemari anak sekolah dasar

5) Gaya bahasa yang digemari anak sekolah dasar

6) Tegangan yang digemari anak sekolah dasar

7) Suasana yang digemari anak sekolah dasar

\section{METODE PENELITIAN}

Populasi penelitian ini ialah para siswa SD kelas IV - VI. Pertimbangan yang digunakan tidak melibatkan siswa kelas I III karena siswa ini masih dalam taraf membaca permulaan, sementara data yang dikumpulkan menghendaki pemakaian kuesioner untuk mengumpulan data kegemaran. Atas dasar ini, sampel ditarik dengan teknik purposive random sampling.
Berdasarkan hal ini, maka sampel penelitian menjadi sebagai berikut: (1) SD dalam kota terdiri atas (a) SD 1 Banjar Jawa, (b) SD 3 Banjar Jawa; (2) SD pinggiran terdiri atas (a) SD 1 Sangsit, (b) SD 1 Temukus; dan (3) SD luar kota (a) SD 2 Jinengdalem, dan (b) SD 2 Banjar.

Data yang dikumpulkan ialah unsurunsur yang menyebabkan anak gemar terhadap film cerita asing, yaitu kegemaran unsur instrinsik dan unsur kognitif. Kegemaran di sini diartikan sebagai intensitas dorongan dari dalam hati anak untuk menonton film cerita.Sebab itu, data kegemaran dijaring dengan kuesioner. Pemahaman unsur intrinsik ialah kemampuan siswa dalam memahami unsur intrinsik (tema, latar, tokoh, alur, gaya bahasa, suasana dan kegiatan). Berdasarkan hal ini, maka data penelitian yang berkaitan dengan kegemaran di kumpulkan dengan kuesioner berjumlah 25 dan data pemahaman unsur intrinsik dikumpulkan dengan tes yang berjumlah 20 .

Contoh kuesioner kegemaran

- Menurut anak-anak apakah isi cerita film Ipin Upin yang berjudul Basikal dapat menghibur anak-anak ?
(a) sangat menghibur
(c) cukup menghibur
(e) sangat tidak menghibur
(b) menghibur
(d) tidak menghibur

Contoh tes pemahaman unsur intrinsik

- Setelah anak-anak menonton film Ipin-Upin berjudul Basikal Baru apa isi film tersebut.
(a) melawan kejahatan
(c) ucapan terimakasih
(e) sangat tidak menghibur
(b) belas kasihan
(d) tidak menghibur 
Tes yang berjumlah dua puluh ini masingmasing diberi skor 5 untuk setiap jawaban benar. Dengan demikian bila semua jawaban benar, maka siswa akan memperoleh nilai 100. dan bila semua salah akan memperoleh nilai 0 . Untuk menentukan kualitas kemampuan siswa dalam memahami unsur intrinsik digunakan kriterium sebagai berikut.

\begin{tabular}{|c|c|c|}
\hline \hline No & Nilai & Predikat \\
\hline 1. & $85-100$ & Sangat baik \\
\hline 2. & $70-84$ & Baik \\
\hline 3. & $55-69$ & Cukup \\
\hline 4. & $45-54$ & Kurang \\
\hline 5. & $0-44$ & Jelek \\
\hline
\end{tabular}

(Dantes dan Rasna, 1995:72)

Setelah data terkumpul, data diolah secara kualitatif.

\section{HASIL PENELITIAN}

1. $89 \%$ anak siswa SD menyukai film anak - anak yang lucu, apapun temanya. Umumnya tema yang disukai adalah dunia binatang, yang dapat bicara seperti manusia, kura-kura, singa, gajah dan lain-lain.

2. Alur yang disukai anak SD ialah alur cerita yang tidak berliku-liku, tidak rumit. Alur yang baik adalah alur cerita yang menggerakkan anak kepada tokoh yang baik. 92\% anak SD menyukai cerita yang sederhana.

3. Perwatakan yang dikemari oleh anakanak adalah watak yang menunjukkan moral yang baik dan perilaku yang santun. Bahkan, anak-anak cepat sekali menaruh iba kepada tokoh protagonis.

4. Latar yang digemari anak adalah latar yang indah, bagus dan dekat dengan lingkungan anak. Bila latarnya bagus, tetapi tidak ada di lingkungan anak, hal ini membuat anak mengkhayal. Bila latarnya jelek, dan itu ada pada tokoh idola, maka hal ini membuat anak iba akan keadaan tokoh idola.

5. Gaya bahasa yang disukai anak adalah bahasa menghibur dan disampaikan dengan kata-kata konkret sesuai dunia anak-anak, mudah dimengerti/kalimatnya sederhana, tetapi efektif.

6. Tegangan yang digemari anak adalah tegangan yang membuat anak untuk selalu ingin tahu lanjutan cerita itu. Dari sinilah anak akan selalu menantikan kapan lanjutan cerita itu ditayangkan/diceritakan kembali. Namun, harus diwaspadai dan dicermati bahwa jangan sampai tegangan itu tidak terkontrol. Artinya tegangan itu tidak membawa anak kepada suasana hati yang emosi, tetapi tegangan itu membuat anak untuk menggunakan akal budi, pikiran yang baik dan berguna.

7. Suasana yang digemari anak adalah suasana cerita yang menghibur.

\section{PEMBAHASAN}

Anak - anak menggemari film anak ang lucu disebabkan oleh anak pada usianya memang sedang dalam posisi usia untuk menikmati hiburan. Anak -anak menyukai dunia dunia binatang dapat berbicara seperti manusia karena pada masa anak-anak ini jiwa anak masih kosong/bersih yang haus dan sedang mengharapkan adanya pencerita yang mampu mengisi kekosongan jiwa ini. Jika pengisian jiwa yang masih kosong ini diisi dengan baik dan benar, maka anak akan tumbuh dan berkembang menjadi anak yang 
baik. Tetapi jika pengisian ini salah, artinya diisi dengan adegan - adegan kekerasan, fornografi misalnya, maka jiwa akan terpengaruh. Hal ini sangat membahayakan. Sebab, itu cerita anak-anak harus diseleksi. Dan di sinilah sebenarnya peran orang tua mendongengkan putra - putrinya.

Anak SD menyukai alur sederhana. Hal ini mudah dipahami, karena anak-anak masih dalam taraf berpikir operational konkret, sehingga kalimat yang digunakan sederhana dengan kosakata anak-anak, bukan kosakata orang dewasa.

Perwatakan yang disukai anak adalah watak yang baik, seperti penolong, halus. Sebab itu, jika terdapat tokoh yang berwatakan kasar, anak cepat sekali membencinya. Hal ini mudah dipahami karena anak memang anak masih dalam taraf berpikir tunggal dan belum mampu berpikir majemuk.

Latar yang disukai anak adalah latar yang mudah dicarikan pembandingnya di lingkungan anak.. Hal ini terjadi karena anak menginginkan kebenaran itu dapat dengan mudah dibuktikan keberadaannya.Dan ini merupakan ciri pembeda anak sekarang dengan anak dulu.Karena mereka tidak mau menerima begitu saja, tetapi mereka bertanya kenapa begini, kenapa begitu, yang berbeda dengan anak dulu yang mau menerima begitu saja. Jika latarnya jelek, anak cepat menaruh rasa iba pada tokoh tersebut.

Gaya bahasa yang disukai anak adalah gaya bahasa menghibur. Hal ini tentu sejalan dengan perkembangan anak yaitu anak ada dalam posisi/masa bermain. Pada masa ini anak membutuhkan teman/kawan yang bisa diajaknya bermain untuk menghibur dirinya. Oleh karena itu, bila yang diajaknya bermain adalah orang dewasa/orang tua, maka orang dewasa/ orang tua itu harus mampu berlaku seperti anak-anak. Sebab, hanya dengan begitu anak-anak akan merasa terhibur. Jika tidak, anak akan kecewa dan menangis.

Tegangan yang disukai anak adalah tegangan yang membuat anak untuk selalu ingin tahu lanjutan cerita itu. Keadaan ini membuat anak untuk selalu menantikan kapan cerita itu dilanjutkan/ditayangkan /diceritakan kembali. Hal ini sebenarnya adalah tanda yang baik bagi pencerita. Sebab pencerita telah mampu membawa anak untuk selalu mengikuti dan menantikan lanjutan cerita tersebut. Namun harus diwaspadai, jangan sampai tegangan itu membawa anak kepada suasana hati emosi. Apalagi membawa anak untuk mempraktekkan ketegangan itu seperti yang dilakukan oleh tokoh. Harus dibuat/diantarkan anak itu untuk memakai akal budi, pikiran yang baik dan berguna. Jadi tegangan tidak dimaksudkan untuk membuat anak tegang dan bersitegang, tetapi melatih anak untuk berpikir.

Suasana yang digemari anak adalah suasana yang menghibur. Hal ini tentu sesuai dengan taraf perkembangan anak.

\section{SIMPULAN}

Model cerita asing yang digemari anak adalah model cerita yang memenuhi persyaratan sebagai berikut.

1. $89 \%$ anak siswa SD menyukai film anak - anak yang lucu, apapun temanya. Umumnya tema yang disukai adalah dunia binatang, yang dapat bicara seperti manusia, kura-kura, singa, gajah dan lain-lain.

2. Alur yang disukai anak SD ialah alur cerita yang tidak berliku-liku, tidak rumit. Alur yang baik adalah alur cerita yang menggerakkan anak kepada 
tokoh yang baik. 92\% anak SD menyukai cerita yang sederhana.

3. Perwatakan yang dikemari oleh anakanak adalah watak yang menunjukkan moral yang baik dan perilaku yang santun. Bahkan, anak-anak cepat sekali menaruh iba kepada tokoh protagonis.

4. Latar yang digemari anak adalah latar yang indah, bagus dan dekat dengan lingkungan anak. Bila latarnya bagus, tetapi tidak ada di lingkungan anak, hal ini membuat anak mengkhayal. Bila latarnya jelek, dan itu ada pada tokoh idola, maka hal ini membuat anak iba akan keadaan tokoh idola.

5. Gaya bahasa yang disukai anak adalah bahasa menghibur dan disampaikan dengan kata-kata konkret sesuai dunia anak-anak, mudah dimengerti/kalimatnya sederhana, tetapi efektif.

6. Tegangan yang digemari anak adalah tegangan yang membuat anak untuk selalu ingin tahu lanjutan cerita itu. Dari sinilah anak akan selalu menantikan kapan lanjutan cerita itu ditayangkan/diceritakan kembali. Namun, harus diwaspadai dan dicermati bahwa jangan sampai tegangan itu tidak terkontrol. Artinya tegangan itu tidak membawa anak kepada suasana hati yang emosi, tetapi tegangan itu membuat anak untuk menggunakan akal budi, pikiran yang baik dan berguna.

7. Suasana yang digemari anak adalah suasana cerita yang menghibur

\section{SARAN}

Saran yang diajukan berkaitan dengan hasil penelitian ini diajukan kepada.
1. Pengarang cerita anak perlu mempertahankan unsur intrinsik yang membangun cerita itu agar cerita itu digemari anak.

2. Pengarang cerita hendaknya tak pemah berhenti mengarang cerita anak dengan memperhatikan unsure karakter sebagai materi utama.

\section{UCAPAN TERIMAKASIH}

Ucapan terimakasih ini disampaikan kepada Direktorat Jenderal Pendidikan Tinggi, Kementerian Pendidikan Nasional yang telah memberikan dana melalui penelitian Hibah Bersaing dengan Kontrak Nomor $\quad$ 043/SP2H/PL/ditlitabmas./IV/2011 Tanggal 11 April 2011.

\section{DAFTAR PUSTAKA}

Bali Post, 1996. Hilangnya Keakraban hubungan Guru-Murid di Bali:

Dumadi, Sagimun Mulus.1955. Pembentukan dan Fendidikan Watak. Jakarta Noordoff-KolfflV.V

Effendi, Samsoeri. 1982. Etiket Sopan Santun Fergaulan Menurut Tatakrama Nasional. Surabaya: Karya Anda

Esten Mursal. 1985. Tinjauan Tema dan Arnanat serta Latar dan Tokoh Tenggelamnya Kapal Van der Wijck dan Salah Asuhan. Jakarta: Pusat Pembinaan dan Pengembangan Bahasa

Ikram, Achdiati, 1980. Bunga Rarnpai Bahasa, Sastra dan Budaya. Jakarta: Interrnasa

Marcus, A.S. 1984. Petunjuk Mengarang Cerita Anak-Anak. Jakarta: PT. Rosdajaya Putra

Nadeak, Wilson. 1987. Cara-Cara Bercerita. Jakarta: Bina Cipta

Nadeak, Wilson. 1990. Pengarang dan Editor. Bandung: Yayasan Pustaka Wina

Nazar, Yoeniarsih. 1995. Acara TV untuk Anak Hanya $14 \%$ yang Kena

Jurnal IImu Sosial dan Humaniora | 100 
Sasaran. Jakarta: Konipas 4 Aprii1995 haL47

Partini, Sardjono, Pr.1992. Pengantar Sastra. Bandung: Yayasan Pustaka Wina.

Rusli, M. Iksan. 1993. Pelajar Brutal, Budi Pekerti, dan Nasib Guru. Jakarta: Suara Karya

Said, Muh H. 1980. Etik Masyarakat Indonesia. Jakarta: Pradnya Paramita

Sastrasupono, M. Suprihadi. 1983. Etika Sebuah Pengantar. Bandung: Alumni

Tarigan, Henry Guntur. Prof. Dr. 1995. Psikosastra. Hakikat dan Nilai Sastra bagi Anak-Anak. Bandung: Angkasa

Teeuw, A.A. Prof.Dr.1983. Membaca dan Menilai Sastra. Jakarta: PT Gramedia

Teeuw, A.A. Prof. Dr.1983. Indonesia antara Kelisanan dan Keberaksaraan. Jakarta Pustaka Jaya

Tjitrosubono. 1985. Memahami CerpenCerpen Danarto. Jakarta: Pusat Pembinaan dan Pengembangan Bahasa.

Trin. 1996. Ke Mana Jam Belajar Menghilang. Bali Post 5 Mei1996. Halaman 1.

Wardiman. Atiie. Dr.Dr. 1997. Gunakan Filsafat Semut Mendidik Budi Pekerti Anak. Bali: Bali Post

Widiastono, Tony d. 1993. Kebangkitan Buku Anak-Anak. Jakarta: Kompas 16 Nopember 1993. Halaman 10

Yudiono, K.S. 1981. Bagaimana Mengarang Cerpen. Semarang: CV. Prabhatara 